\title{
11-yr of coral community dynamics in reefs around Dahab (Gulf of Aqaba, Red Sea): the collapse of urchins and rise of macroalgae and cyanobacterial mats
}

\author{
Miriam Reverter $^{1,2}$ (D) Matthew Jackson ${ }^{1,2}$ - Nauras Daraghmeh ${ }^{2,3}$. \\ Christian von Mach $^{2} \cdot$ Nina Milton ${ }^{2}$
}

Received: 17 February 2020/ Accepted: 23 July 2020/Published online: 29 July 2020

(C) The Author(s) 2020

\begin{abstract}
Corals from the Gulf of Aqaba (northern Red Sea) are resilient to high temperatures and therefore this region is regarded as globally important for reef conservation. However, long-term dynamics of coral reef assemblages from the Gulf of Aqaba remain largely understudied. In this study, we analysed the change in benthic, fish and invertebrate assemblages of reefs around Dahab (South Sinai, Egypt) between 2009 and 2019. We also studied the individual trajectories of coral reef benthic categories, key invertebrate and fish species and their relationship. As site emerged as the main factor explaining the variability in coral reef communities, we identified three clusters of sites with similar assemblages. Both benthic, fish and invertebrate assemblages changed considerably at the three site clusters between 2009 and 2019 . We found significant increases in fleshy macroalgae $(\sim 6$ to $15 \%)$ and cyanobacterial mats ( $\sim 6$ to $12 \%)$ in all site clusters. Although not observing a significant reduction of
\end{abstract}

Topic Editor Morgan S. Pratchett

Electronic supplementary material The online version of this article (https://doi.org/10.1007/s00338-020-01988-6) contains supplementary material, which is available to authorised users.

Miriam Reverter

mirireverter@gmail.com

$\triangle$ Christian von Mach

chrisvonmach@redsea-ec.org

1 Institut für Chemie und Biologie des Meeres (ICBM), Carl von Ossietzky Universität Oldenburg, Schleusenstraße 1, 26382 Wilhelmshaven, Germany

2 Red Sea Environmental Centre (RSEC), Dahab, Egypt

3 Department of Marine Ecology, Faculty of Biology and Chemistry, University of Bremen, Bremen, Germany hard coral cover, both macroalgae mat cover and cyanobacterial mat cover were significantly negatively related to hard coral cover and hard coral disease. Soft coral cover (mainly corals from the Xeniidae family) decreased significantly in two of the site clusters, their cover being negatively related to macroalgal and cyanobacterial cover. Significant declines in grazer urchins were observed at all site clusters, and a strong negative relationship was found with macroalgae and cyanobacterial mats cover, suggesting urchin decline as one of the main drivers behind algal increases. Different site clusters had different fish trajectories (butterflyfish, parrotfish, surgeonfish and predators), with only damselfish densities significantly decreasing at all sites. A significant decrease in damselfish densities was related to increases in cyanobacterial mats. These findings suggest that if macroalgae and cyanobacteria continue to increase, Dahab coral reefs could undergo degradation, and therefore, more studies are needed to elucidate the drivers behind these algal increases.

Keywords Coral reef - Gulf of Aqaba - Coral reef resilience · Macroalgae - Cyanobacterial mats · Urchins . Algae phase shift

\section{Introduction}

Coral reefs, which harbour $25 \%$ of the marine biodiversity and provide ecosystem services to over 500 million people, are suffering severe degradation due to the combined effects of anthropogenic perturbations and global climate change (Hughes et al. 2017; Lamb et al. 2018). Anthropogenic disturbances such as overfishing, coastal development and pollution, together with increasing climate 
anomalies reduce coral reef resilience, which can result in changes of coral reef assemblages (Adjeroud et al. 2018; Hughes et al. 2018a; McWilliam et al. 2020). Decreases in coral cover and increases in alternate groups such as algae or sponges are increasingly common and have profound effects on ecosystem functioning and the ecosystem services provided (Done 1992; Norström et al. 2009; Bell et al. 2013). Declines in the scleractinian coral cover of up to $80 \%$ in Caribbean coral reefs and $50 \%$ in the IndoPacific have been reported (e.g. Bruno and Selig 2007; Gardner et al. 2003; Pandolfi et al. 2003; De'ath et al. 2012). More recently, unprecedented pan-tropical mass bleaching, which killed $30 \%$ of the world's largest coral reef ecosystem, the Great Barrier Reef, has raised concerns about the future of coral reefs under pressure in the Anthropocene (Hughes et al. 2017, 2018b).

With the increasing frequency and intensity of bleaching events and estimates predicting $90 \%$ of the world's coral reefs are expected to experience severe bleaching by 2050 (van Hooidonk et al. 2014; Heron et al. 2016), conservation of regions with heat-tolerant corals is paramount. The Red Sea, which extends between the Arabian Peninsula and the African mainland, is one of the world's warmest $\left(20-28{ }^{\circ} \mathrm{C}\right.$ in the Northern Red Sea and $28-35{ }^{\circ} \mathrm{C}$ in the Southern Red Sea) and most saline water bodies (36-42 ppt) hosting highly diverse coral reefs (Abdelmongy and El-Moselhy 2015; Rasul et al. 2015). Despite the northern Red Sea displaying the highest rates of warming throughout the Red Sea (Chaidez et al. 2017), including more severe thermal anomalies (Osman et al. 2018), this region has not experienced massive coral bleaching events. Due to this high coral heat tolerance, the northern Red Sea has been proposed as a coral refuge of global importance, as this region may host a gene pool of heat-resistant scleractinian corals that could be extremely useful for reef restoration efforts around the world (Fine et al. 2013). Coral reefs in the Gulf of Aqaba are, however, subject to increasing anthropogenic disturbances mostly linked to the development of the tourism sector (Rinkevich 2005; Naumann et al. 2015). Previous studies have shown the deleterious effects of intensive diving and snorkelling activities, coastal development and eutrophication on the health of northern Red Sea coral reefs (Zakai and Chadwick-Furman 2002; Hasler and Ott 2008; Naumann et al. 2015). Short-term studies in the area $(1-3 \mathrm{yr})$ have reported increases in the cover of turf algae and macroalgae, which were positively correlated to environmental nutrient levels (Bahartan et al. 2010; Naumann et al. 2015). Algae are fierce spatial competitors, and at high abundances they have multiple effects on coral health and impair coral and fish recruitment (Rasher and Hay 2010; Dixson et al. 2014). Herbivores (both fish and invertebrates such as sea urchins) are vital to control algal proliferation and ensure space for coral recruitment and regrowth (Williams and Polunin 2001; Burkepile and Hay 2008; Sandin and McNamara 2012). However, when herbivory capacity is reduced, for example due to overfishing or algal deterrence, algae can proliferate and disrupt coral reef functioning, leading to coral reef degradation and a community phase shift (Bellwood et al. 2004; Hoey and Bellwood 2011). Given the key importance of the Gulf of Aqaba region at a global scale, long-term studies are needed to investigate the dynamics and state of its coral reef assemblages and evaluate the full implications of the previously reported algal increases, in order to establish adequate conservation measures.

In this study, we have surveyed fringing reefs in the Dahab area (South Sinai, Egypt) between 2009 and 2019. Dahab is a world-renowned dive destination since the late 1990s and its reefs are amongst the world's most dived upon $(30,000$ dives/yr) (Hasler and Ott 2008). We collected data on the reef benthos composition, the abundance of diseased coral colonies and the densities of key invertebrate and fish species in order to: (1) study whether there were significant temporal changes in reef benthos assemblages or fish and invertebrate communities and (2) analyse individual temporal trajectories of benthos categories, colonies of diseased coral and key invertebrate and fish species. We also explored the relationships between different organisms to explore the following hypotheses: (1) whether macroalgae and cyanobacterial mats affect hard and soft coral cover and the abundance of hard coral diseases and (2) if top-down control (from herbivorous fish or herbivorous invertebrates such as urchins) is related to changes in fleshy macroalgae and cyanobacterial mats cover.

\section{Materials and methods}

\section{Coral reef surveys}

A total of 11 fringing reefs around Dahab in the northern Red Sea were surveyed twice a year (August-September and March-April) between 2009 and 2019 using four endto-end $20 \mathrm{~m}$ transects perpendicular to the reef slope (Fig. 1a). Surveys were carried out by volunteers trained and supervised by professional scientists (ESM Supplementary Information). Benthic composition, coral damage and invertebrate and fish indicator species were monitored at each site at 5 and $10 \mathrm{~m}$ depth, using SCUBA. Due to logistics, not all sites and depths were monitored at each sampling episode (ESM Table 1). Benthic composition was determined using the point intercept transect (PIT) method (Hill and Wilkinson 2004), in which the benthos categories lying under a point of the transect line were recorded every $50 \mathrm{~cm}$. We classified scleractinian corals according to their morphology, as this is an important trait 


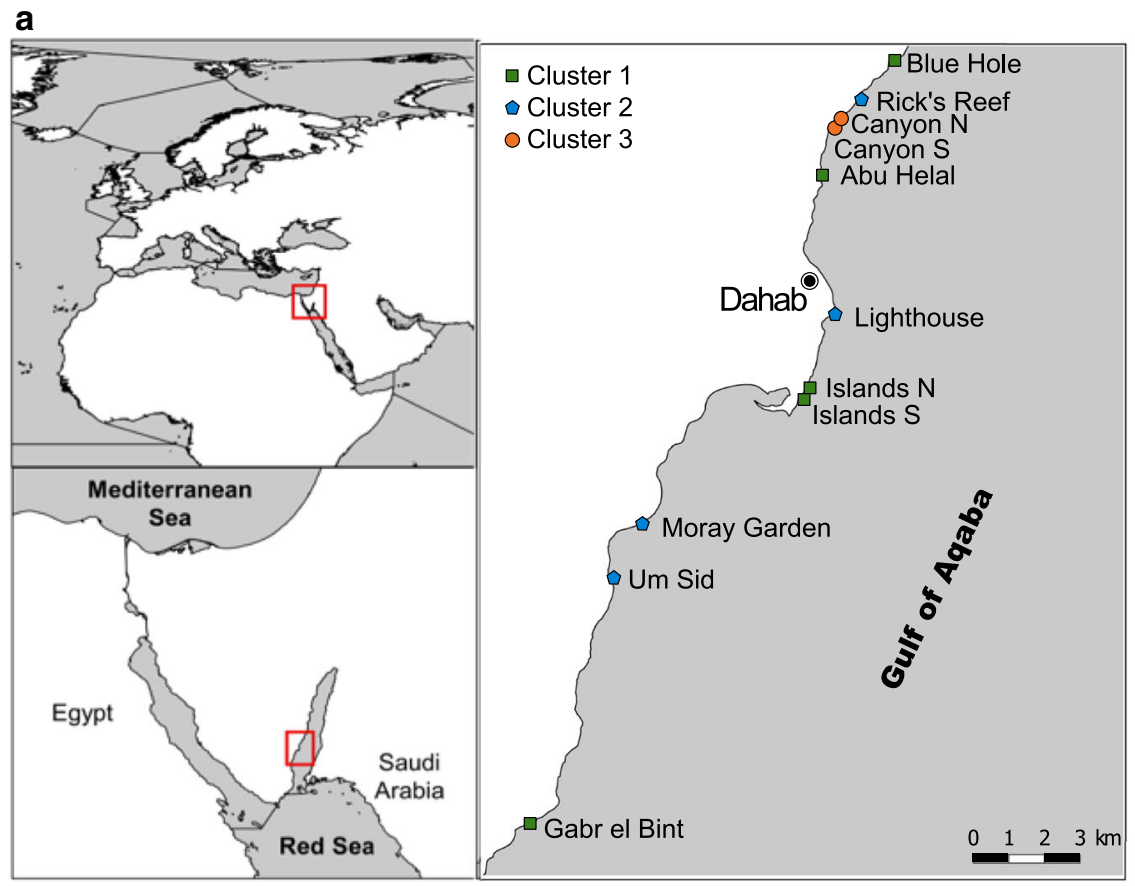

b

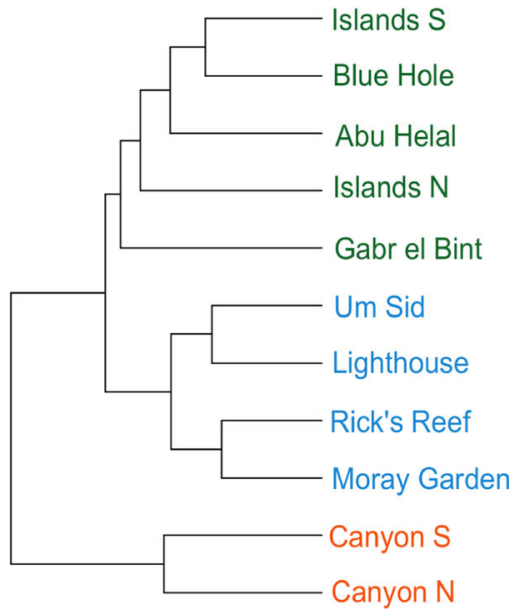

Fig. 1 a Map with the surveyed sites within the Dahab region (Southern Sinai, Egypt), and the site cluster identified by colour. b Cluster analysis of the dissimilarities between sites and

in coral functioning and in coral reef structural complexity (Darling et al. 2012). Twenty-three benthic categories were used: branching hard coral (HC), columnar HC, tabular $\mathrm{HC}$, massive $\mathrm{HC}$, encrusting $\mathrm{HC}$, foliose $\mathrm{HC}$, solitary HC (mushroom corals, Fungiidae), Millepora hydrocorals, Alcyoniidae soft corals (SC), Xeniidae SC, Nephtheidae SC, Tubipora spp. SC, zoanthids, other soft corals, sponges, coralline algae, turf algae, fleshy macroalgae, cyanobacterial mats, other benthic living organisms, rock, rubble and fine sediment (sand and silt).

During the coral damage survey, the number of hard coral colonies affected by coral diseases (black band disease, dark spot disease, yellow band disease, skeletal eroding band, and white plague) located within $2.5 \mathrm{~m}$ at each side of the transect line was recorded. Invertebrate and fish indicator species were selected due to their importance in coral reefs. Key invertebrate species (crown of thorns starfish Acanthaster planci, grazer urchins (longspined urchins belonging to the genus Diadema and Echinotrix, pencil urchin Heterocentrotus mamillatus and collector urchin Tripneustes gratilla), giant clams (Tridacna spp.) and corallivorous snails (Drupella spp. and Coralliophila spp.) located within $2.5 \mathrm{~m}$ at each side of the transect line were counted. Fish were counted within $2.5 \mathrm{~m}$ on each side of the transect line and $5 \mathrm{~m}$ above. Monitored fish included damselfishes (Plectroglyphidodon lacrymatus, P. leucozonus and Stegastes nigricans), parrotfishes (Scaridae), surgeonfishes (Acanthuridae), butterflyfishes identification of different clusters (green: cluster 1, blue: cluster 2 and orange: cluster 3 ) of similar sites. $Y$-axis represents the heights at which the clusters diverge

(Chaetodontidae), groupers (Ehinephilinae and Serranidae), snappers (Lutjanidae), sweetlips (Haemulidae), emperors (Lethrinidae), broomtail wrasse (Cheilinus lunulatus) and humphead wrasse (Cheilinus undulatus). Due to low abundances of predator fish (trophic levels $\geq 3$ : groupers, snappers, sweetlips, emperors and wrasses) these fish were grouped in the single category "predators" for statistical analysis.

\section{Data analysis}

Benthos composition data were expressed as \% of cover, whereas densities of invertebrates (individuals $/ \mathrm{m}^{2}$ ) and fish (individuals $/ \mathrm{m}^{3}$ ) were calculated. Hellinger-transformed data, using the function "decostand" from vegan package (Oksanen et al. 2019), were used for multivariate analyses, whereas non-transformed data (\% cover or densities) were used for univariate models. All analyses were performed on $\mathrm{R}$ version 3.5.1.

We used redundancy analysis (RDA) with variation partitioning (Borcard et al. 1992) to assess the relative contribution of site, year, season and depth on the coral reef community (benthos or invertebrates and fish) variability (function "varpart", package vegan). This method partitions the global variation into the different components of interest, their interactions and the residual component using adjusted- $R^{2}$ values that correct for the variation jointly explained by multiple variables (Peres-Neto et al. 2006). 
Since site aroused as the factor explaining most of the coral community variability, we used a hierarchical cluster analysis (function hclust in R) using Euclidian distance to identify clusters of similar sites (benthos, invertebrate and fish data combined). The "Average" algorithm was chosen after analysis of the cophenetic correlation coefficients (Pearson correlation between the cophenetic distances calculated on cluster branches and the coral community dissimilarity matrix) and the Kelley-Gardner-Sutcliffe (KGS) penalty function was used to prune the dendrogram. Non-metric multidimensional scaling (nMDS) analysis was used to visualise the differences between coral community composition amongst years and clusters of sites. "metaMDS" function (vegan package) was used to perform the nMDS analysis with random starts to reach a stable solution. Then, the "envfit" function (vegan package) was used to plot categories highly correlated to the nMDS distribution $\left(R^{2}>0.8\right.$ and $P$-value $\left.<0.05\right)$.

In order to study changes in similar coral reef assemblages over time, we performed nMDS analyses of (1) benthos and (2) fish and invertebrates data for each of the site clusters previously identified. Species highly correlated to the observed temporal changes were then plotted to the ordination as explained before.

In order to study the change of individual groups over time, cover of the different benthic groups (cover $>5 \%$ in at least 8 transects), number of diseased coral colonies and fish and invertebrate densities were modelled as a function of time (year) using generalised additive mixed models (GAMMs, package gamm4) with site, depth and season as random effects. GAMMs are a non-parametric extension of General Linear Mixed Models (GLMMs) that use smooth functions of the explanatory variable and are therefore suitable for non-linear relationships such as those encountered in ecological data (Guisan et al. 2002). Nested models (with different combinations of the random effects) were built. The difference in Akaike Information Criterium with correction for small sample sizes (AICc) values between each model and the best fitting model with the lowest AICc $(\triangle \mathrm{AICc})$ was used to determine the strength of each model. Akaike weights (wi), which determine the weight of evidence of each model relative to the set of candidate models, were then used to select the model with the best fit (model with the highest weight, "MuMIn" package, Barton 2019) (Arnold 2010). Model residuals were explored with variogram plots, which showed no significant auto-correlation within the data.

Nested linear mixed models were constructed ("Ime4" package, Bates et al. 2019) to investigate (1) how fleshy macroalgae and cyanobacterial mats affected hard and soft coral cover and hard coral disease and (2) how urchins and herbivore fish (damselfishes, parrotfishes and surgeonfishes) densities were related to fleshy macroalgae and cyanobacterial mats cover. Site, depth and season were included as random effects, and the model with the best fit was selected using Akaike weights, as previously described for GAMM models.

\section{Results}

\section{Important components in variation of coral reef communities}

The relative contribution of reef site, year, depth and season to the variability of the coral reef communities was assessed using a redundancy analysis with variation partition. Coral reef site was identified as the factor explaining the highest variance in both benthic composition (21\%) and fish and invertebrate communities (13\%) (ESM Fig. 1). Year was the second most important factor and explained $5 \%$ of the balanced variation of benthic composition and $8 \%$ of fish and invertebrate communities' variance. Depth and season were also significant factors in coral reef communities, but only accounted for 3 and $1 \%$ of the benthic composition variance, respectively (ESM Fig. 1a), and 1 and $2 \%$ of the fish and invertebrate balanced variation (ESM Fig. 1b). Finally, a considerable amount of variance remained unexplained (residual variance) in both benthic composition and fish and invertebrate communities by the studied components (ESM Fig. 1).

\section{Identification of similar sites}

Since site was identified as the main component explaining the variability in both benthos and fish and invertebrate communities we used a hierarchical cluster analysis to identify groups of similar sites before further analysing the data. We identified three different clusters (Fig. 1a, b, ESM Fig. 2). Cluster 1 contained the sites of Abu Helal, Blue Hole, Gabr el Bint, Islands North and Islands South and comprised reefs with varied topography (shallow fore reefs and reef slopes), with the highest hard and soft coral covers and the lowest scuba diving and fishing impacts (ESM Table 2, Fig. 1). Cluster 2 was composed of the sites of Lighthouse, Moray Garden, Rick's Reef and Um Sid and was characterised by sites that displayed higher scuba and fishing impacts and algal abundances (ESM Table 2, Fig. 1). Distance to the nearest population centre (Dahab with 15,000 people) did not seem a determinant in the clustering, since both cluster 1 and cluster 2 included sites close to urban areas (Islands N and S and Lighthouse) and further away (Blue Hole, Gabr el Bint, Um Sid and Moray Garden). Finally, cluster 3 contained the sites of Canyon North and Canyon South (Fig. 1b), and was the most 
different cluster, which was explained by a higher abundance of fine sediment (Fig. 1b, ESM Fig. 2).

\section{Changes in coral reef assemblages over time}

The benthic community structure changed over the last decade at the three site clusters (Fig. 2). Clusters 1 and 2 displayed a shift in benthic communities away from Xeniidae soft corals and towards cyanobacterial mats in recent years, with cluster 2 also shifting towards fleshy macroalgae (Fig. 2). Cluster 3 also presented a shift towards fleshy macroalgae in recent years (Fig. 2). Fish and invertebrate communities changed rather linearly in the site clusters 2 and 3, moving towards communities with higher densities in Tridacna spp. and lower densities of urchins, whereas no clear pattern on fish and invertebrate communities was observed for cluster 1 (Fig. 2). Time trajectories of benthic, invertebrate and fish
groups

\section{Benthic categories}

Hard coral cover increased by 30\% between 2009 and 2019 at sites from cluster 1, which was mostly supported by increases in branching (by $\sim 60 \%$, mostly Acropora coral) and encrusting hard coral (by 19\%) (Fig. 3, ESM Tables 3-4, 8). Solitary corals of the Fungiidae family also increased significantly during the period studied but their overall cover remained under $5 \%$ (Fig. 3, ESM Tables 7-8). Hard coral cover in sites from cluster 2 did not show a significant change over the studied period, despite significant variability in the cover of encrusting and solitary hard corals (Fig. 3, ESM Tables 3, 6-8). Hard coral cover from Canyon $\mathrm{N}$ and Canyon $\mathrm{S}$ (cluster 3) was remarkably lower than cover from the other sites, but no significant changes in the cover were observed between
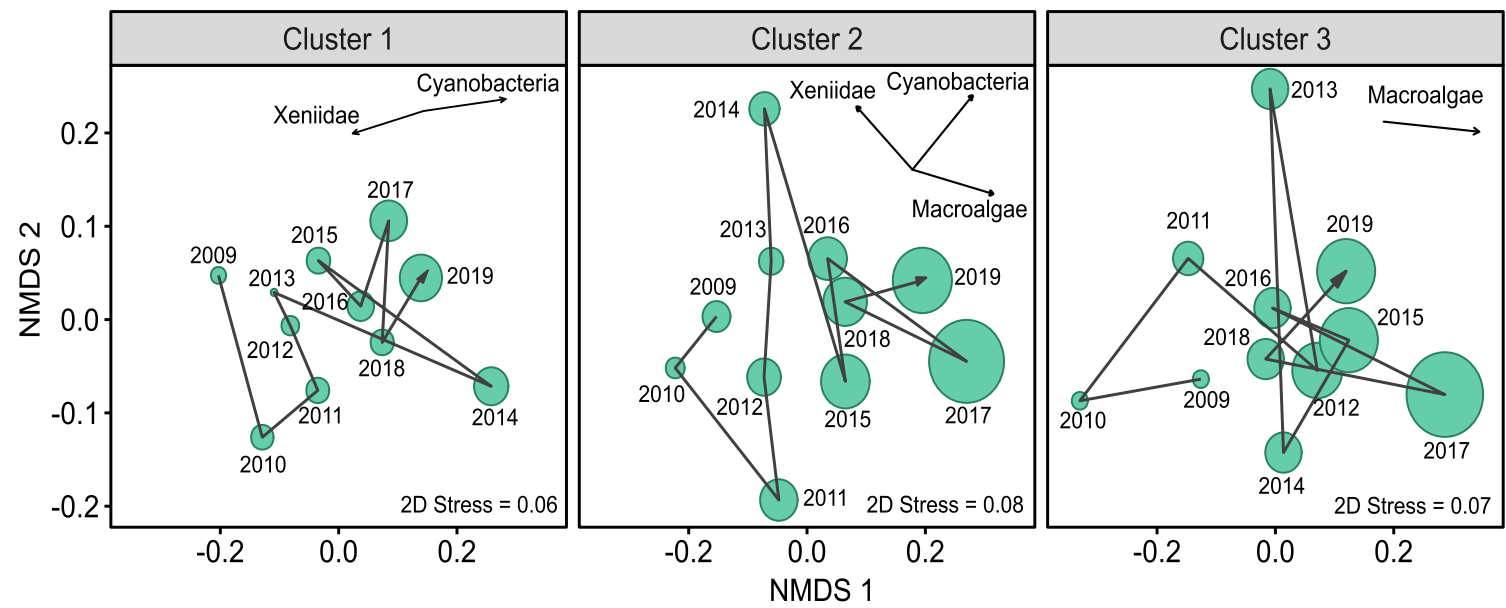

Macroalgae(\%)
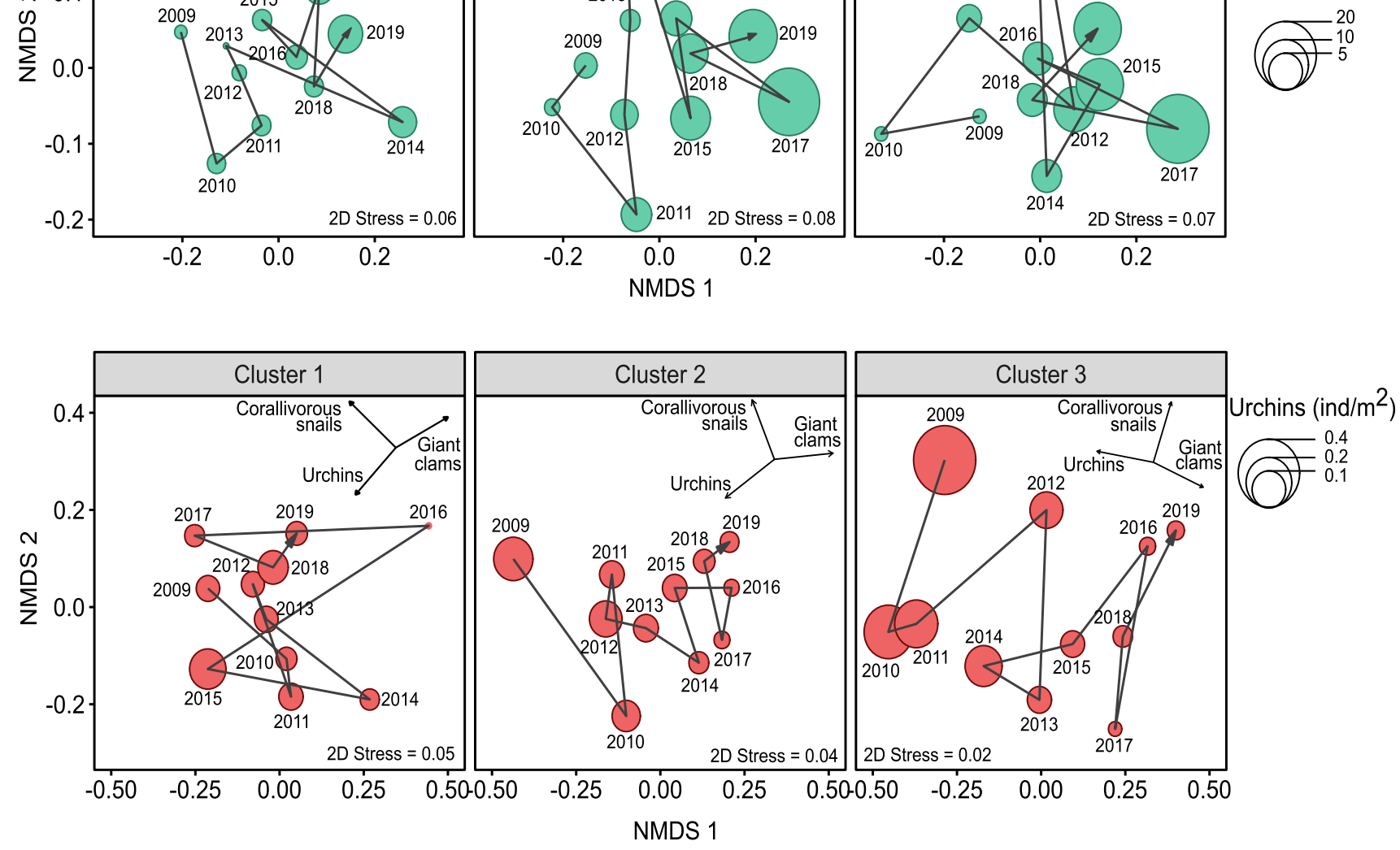

Fig. 2 Changes in coral community assemblages (benthic composition-first row, fish and invertebrate communities-second row) over time visualised as two dimensional non-metric Multidimensional

Scaling Plot (nMDS) for each of the site clusters. Vector plots show the functional groups that contributed significantly $(P<0.05$, $\left.R^{2}>0.8\right)$ to the coral community changes 

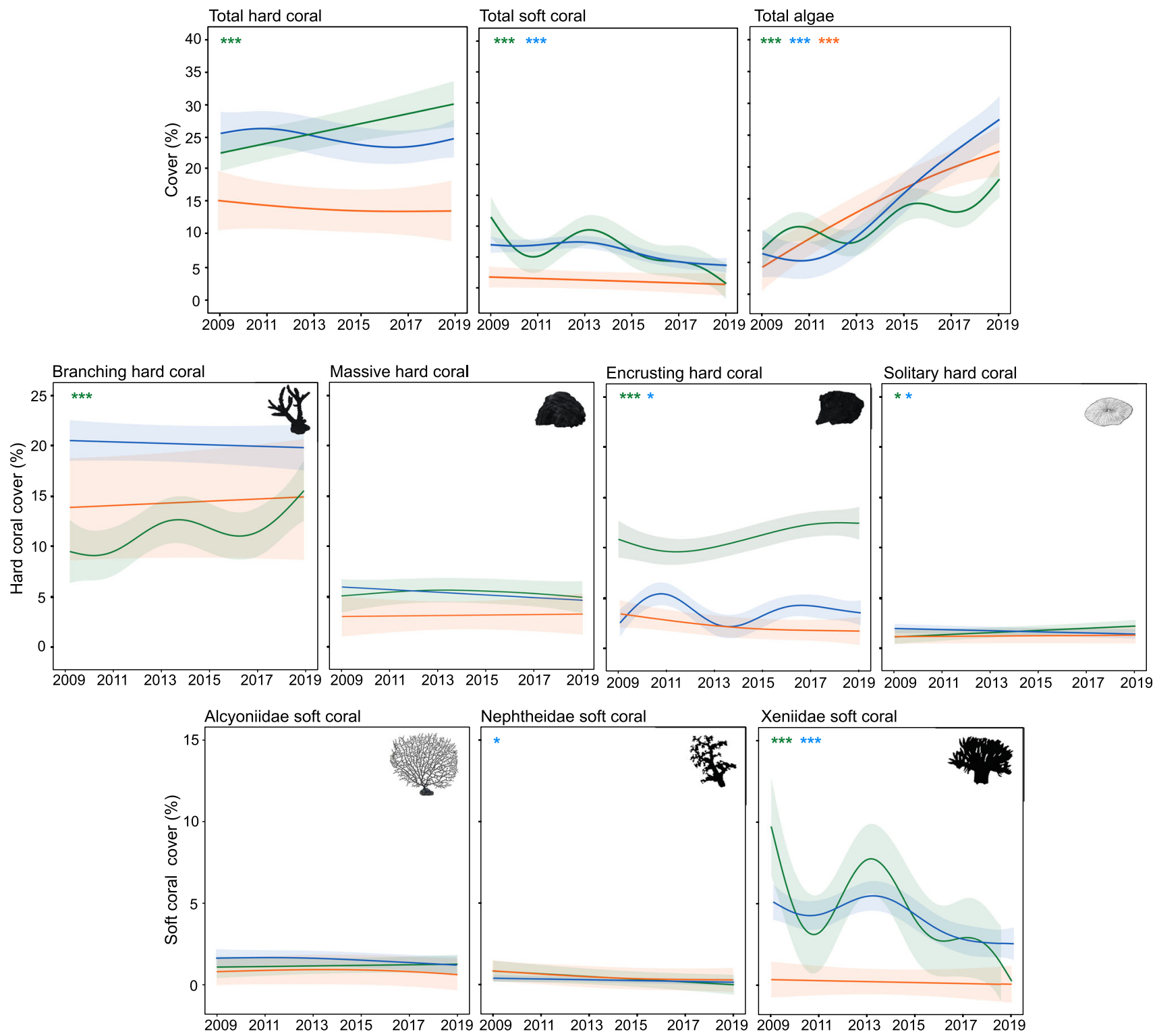

Nephtheidae soft coral
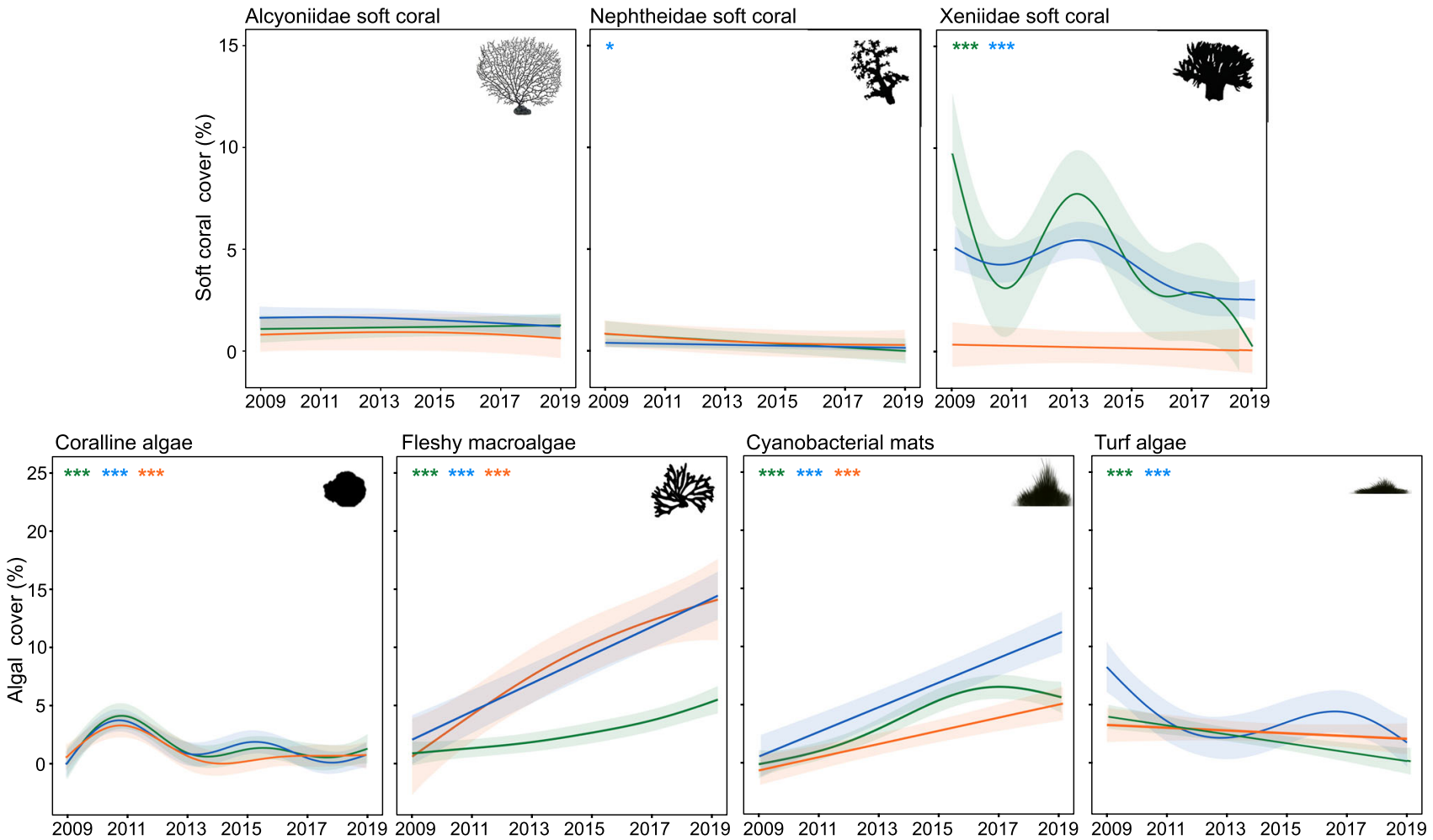

Fig. 3 Individual temporal trajectories of benthic categories $(\%$ cover) between 2009 and 2019 at the three site clusters (green: cluster models (GAMM) with $95 \%$ confidence bands. Statistical significance of the smoother (year): $*<0.05, * * *<0.001$ 
2009 and 2019 (Fig. 3, ESM Tables 3, 8). Massive hard coral cover did not change significantly in any of the site clusters (Fig. 3, ESM Tables 5, 8).

Between 2009 and 2019, soft coral cover decreased significantly by $\sim 53 \%$ and $\sim 38 \%$ in sites from cluster 1 and cluster 2, respectively (Fig. 3, ESM Tables 9, 13). These decreases were mainly supported by decreases in the most abundant soft coral family observed, the Xeniidae, which decreased by $\sim 51 \%$ in the sites from cluster 1 and by $\sim 40 \%$ in the sites from cluster 2 (Fig. 3, ESM Tables 12, 13). Sites from cluster 2 also experienced a decrease in soft corals from the Nephtheidae family, although their average cover was initially low $(\sim 1 \%)$ (Fig. 3, ESM Tables 11, 13). No significant changes in soft coral cover were observed in sites from cluster 3 , however, as with hard coral, these sites displayed significantly lower soft coral covers $(<5 \%)$, especially of the Xeniidae family $(<2 \%)$ (Fig. 3, ESM Table 9, 12-13). Soft corals from the Alcyoniidae family did not change significantly in any of the site clusters (Fig. 3, ESM Tables 10, 13).

Total algal cover increased significantly in all the studied sites between 2009 and 2019, with fleshy macroalgae and cyanobacterial mats as the major responsible groups for such increases (Fig. 3, ESM Tables 14-19). Steep increases of fleshy macroalgae were observed in cluster 2 and 3, where macroalgae was nearly non-existent in 2009 and rose to $\sim 15 \%$ of the total benthic cover by 2019 (Fig. 3, ESM Tables 16, 19). Macroalgal increase in cluster 1 was also significant (from $\sim 1 \%$ in 2009 to $\sim 6 \%$ in 2019), but was less pronounced (Fig. 3, ESM Tables 16, 18). The largest increase in cyanobacterial mats was observed in cluster 2 (from $\sim 1 \%$ in 2009 to $\sim 11 \%$ in 2019, $P$-value $<$ 0.001 ), whereas increases in clusters 1 and 3 were significant but less marked (from $\sim 1 \%$ in 2009 to $\sim 6 \%$ in 2019, Fig. 3, ESM Tables 17, 19). Cover of coralline algae significantly changed over the years; however, such variations corresponded to yearly oscillations rather than clear increase or decrease patterns (Fig. 3, ESM Tables 15, 19). Finally, turf algae decreased significantly in cluster 2, where cover passed from $\sim 7.5 \%$ to $1 \%$ between 2009 and 2019 (Fig. 3, ESM Tables 18, 19). Results indicate that turf algal cover in cluster 1 also decreased significantly (from $\sim 4 \%$ to $1 \%$ ), although deviance explained by this model was low (adjusted- $R^{2}=0.05$ ) (Fig. 3, ESM Table 18, 19). No significant changes in turf algal cover were observed in cluster 3 (Fig. 3, ESM Tables 18, 19).

At the beginning of the survey in 2009, hard coral cover was the dominant biogenic group in the three site clusters, however, by 2019, only sites from cluster 1 remained dominated by hard coral, whereas algae (fleshy macroalgae and cyanobacterial mats) was the dominant biogenic group in sites from cluster 2 and 3 (Fig. 3).

\section{Coral disease}

In order to study whether coral disease increased in time, we modelled the number of diseased coral colonies over time. The most common observed disease was Skeletal Eroding Band, which appeared often in corals in contact with algae (N. M. personal observation). Black Band Disease was not common in Dahab reefs (reported about once a year), and Dark Spot Disease and White Plague were very rare. Yellow Band Disease was never reported. During the surveyed period (2009-2019), we did not identify any major disease outbreak; however, the number of colonies affected by disease increased significantly over time in the three site groups, with cluster 3 presenting the more constant and steep increase (Fig. 4, ESM Tables 20, 21).

\section{Key invertebrates}

Crown of thorns starfish was monitored throughout the whole period, but only one individual was observed amongst the 824 transects surveyed. GAMM models indicated that corallivore snail (Drupella spp. and Coralliophila spp.) densities changed over time, however the deviance explained by the models was low for the three clusters $(<15 \%)$ (Fig. 5, ESM Tables 22, 25). Giant clam (Tridacna spp.) density significantly increased between 2009 and 2019, especially in clusters 1 and 2 (Fig. 5, ESM Tables 23, 25). Urchin densities declined significantly between 2009 and 2019, which was mainly attributed to the decline in the long-spined urchins Echinotrix spp. and Diadema spp. (Figure 5, ESM Tables 24, 25). Cluster 3 presented the biggest decline; however, in 2009, this group

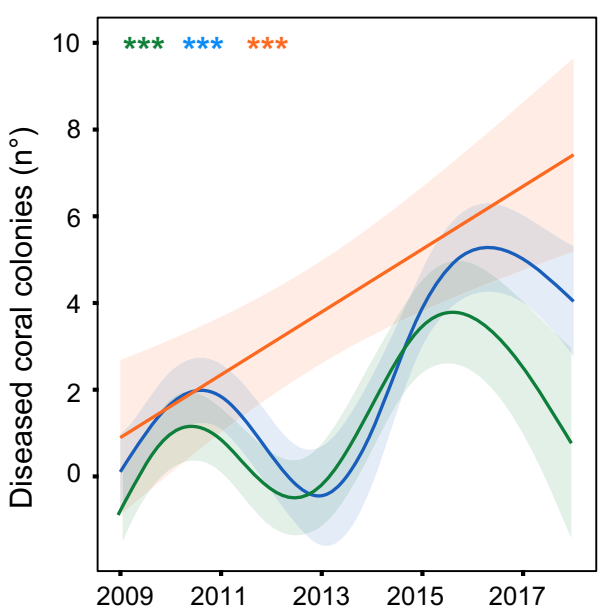

Fig. 4 Individual temporal trajectories of the number of diseased coral colonies between 2009 and 2019 at the three site clusters (green: cluster 1, blue: cluster 2 and orange: cluster 3). Lines represent the estimated models (GAMM) with $95 \%$ confidence bands. Statistical significance of the smoother (year): $* * *<0.001$ 

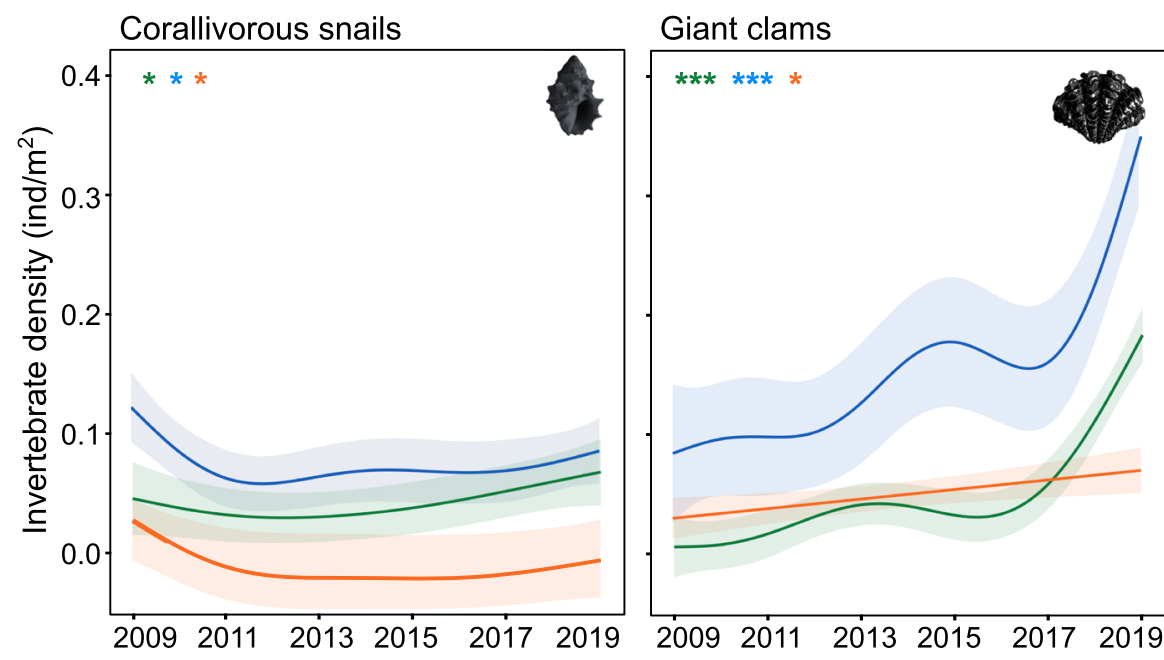

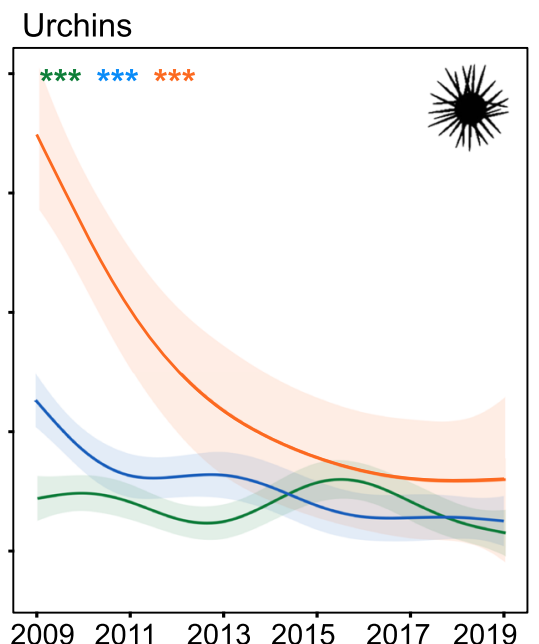

Fig. 5 Individual temporal trajectories of key invertebrates (number of individuals $/ \mathrm{m}^{2}$ ) between 2009 and 2019 at the three site clusters (green: cluster 1, blue: cluster 2 and orange: cluster 3 ). Lines

displayed the greatest urchin densities (Fig. 5, ESM Tables 24, 25).

\section{Key fish groups}

Butterflyfish density changed significantly through the period studied in site clusters 1 and 2, with a significant increase in 2014-2015, a decrease to initial values in 2017 and an increase thereafter (Fig. 6, ESM Tables 26, 31). Similar patterns were observed for surgeonfish from site clusters 1 and 2 and parrotfish and predators from cluster site 1, where fish densities initially decreased between 2009 and 2011, recovered between 2014 and 2015, decreased again in 2016-2017 and increased after 2017 (Fig. 6, ESM Tables 28-31). Predator densities from site cluster 1 also decreased in density between 2009 and 2011, however after their recovery in 2014-2015 remained rather stable (Fig. 6, ESM Tables 30, 31). Butterflyfish from cluster 3 did not change significantly in time, however, surgeonfish and parrotfish in site cluster 3 decreased significantly between represent the estimated models (GAMM) with $95 \%$ confidence bands. Statistical significance of the smoother (year): $*<0.05, * * *<0.001$

2009 and 2019 (Fig. 6, ESM Tables 26, 28, 29, 31). Parrotfish densities in cluster 2 and predator densities in cluster 3 increased linearly between 2009 and 2019 (Fig. 6, ESM Tables 27, 30, 31). Damselfish densities decreased significantly in all site clusters between 2009 and 2019 (Fig. 6, ESM Tables 27, 31).

\section{Relationship between different organisms and macroalgae}

Linear mixed models were used to study (1) how fleshy macroalgae and cyanobacterial mats related to hard and soft coral cover and hard coral disease and (2) how urchins and herbivorous fish (damselfishes, parrotfishes and surgeonfishes) densities were related to fleshy macroalgae and cyanobacterial mats cover. After controlling for site, season and depth when necessary (ESM Tables 32-46), linear mixed models showed that increase in both fleshy macroalgae and cyanobacterial mats was related to significant reductions of hard and soft coral cover (Fig. 7a, b,

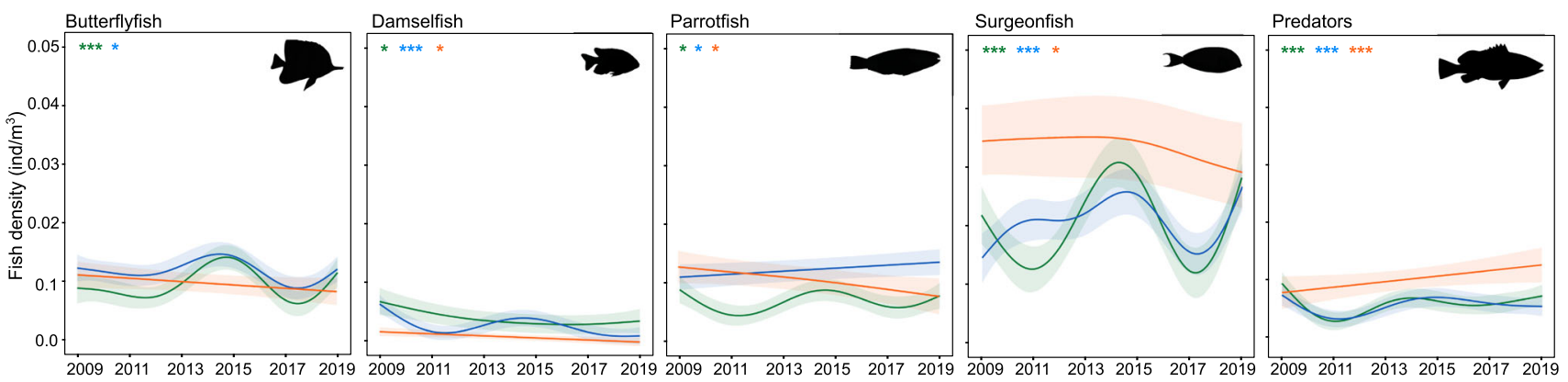

Fig. 6 Individual temporal trajectories of key fish species densities (number of individuals individuals $/ \mathrm{m}^{3}$ ) between 2009 and 2019 at the three site clusters (green: cluster 1, blue: cluster 2 and orange: cluster
3). Lines represent the estimated models (GAMM) with $95 \%$ confidence bands. Statistical significance of the smoother (year): $*<0.05, * * *<0.001$ 
a

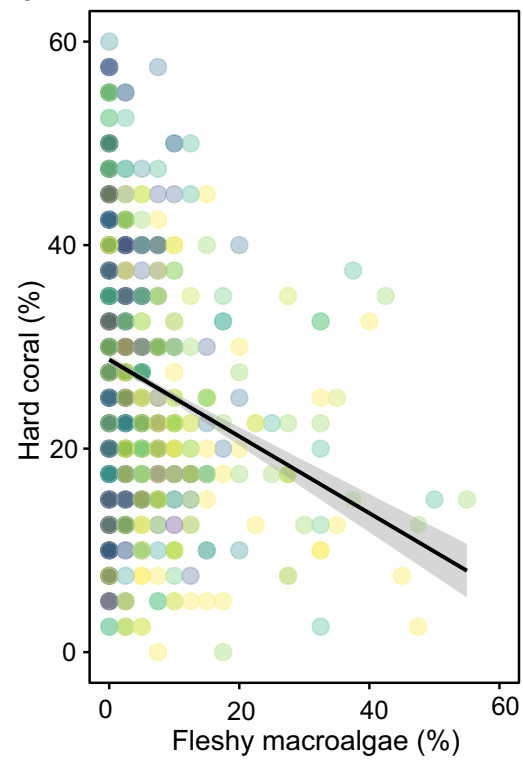

d

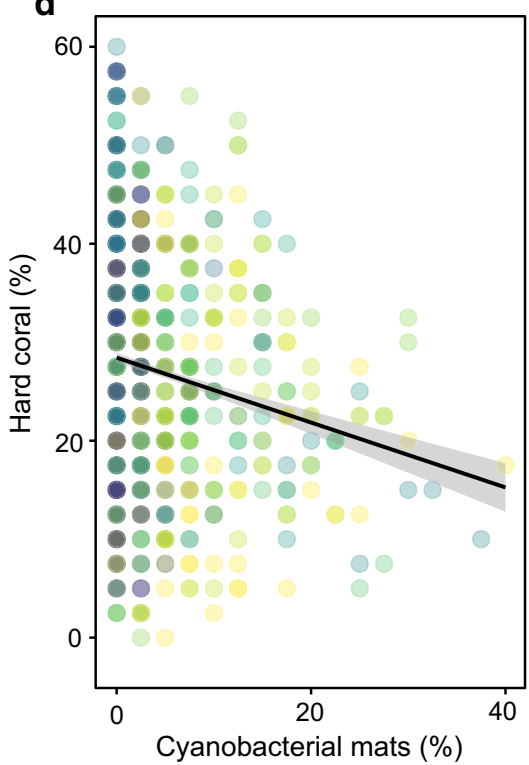

b

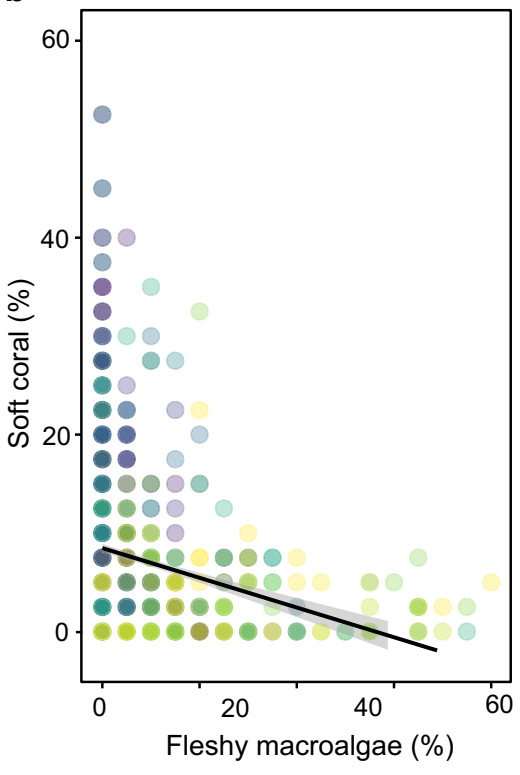

e

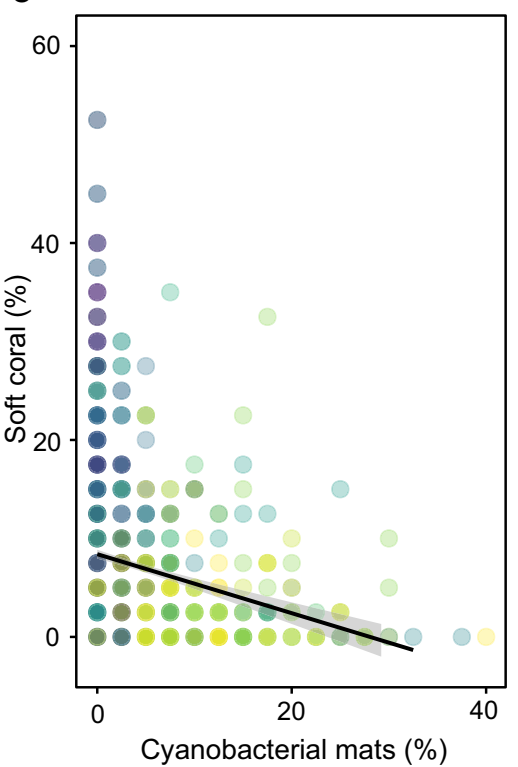

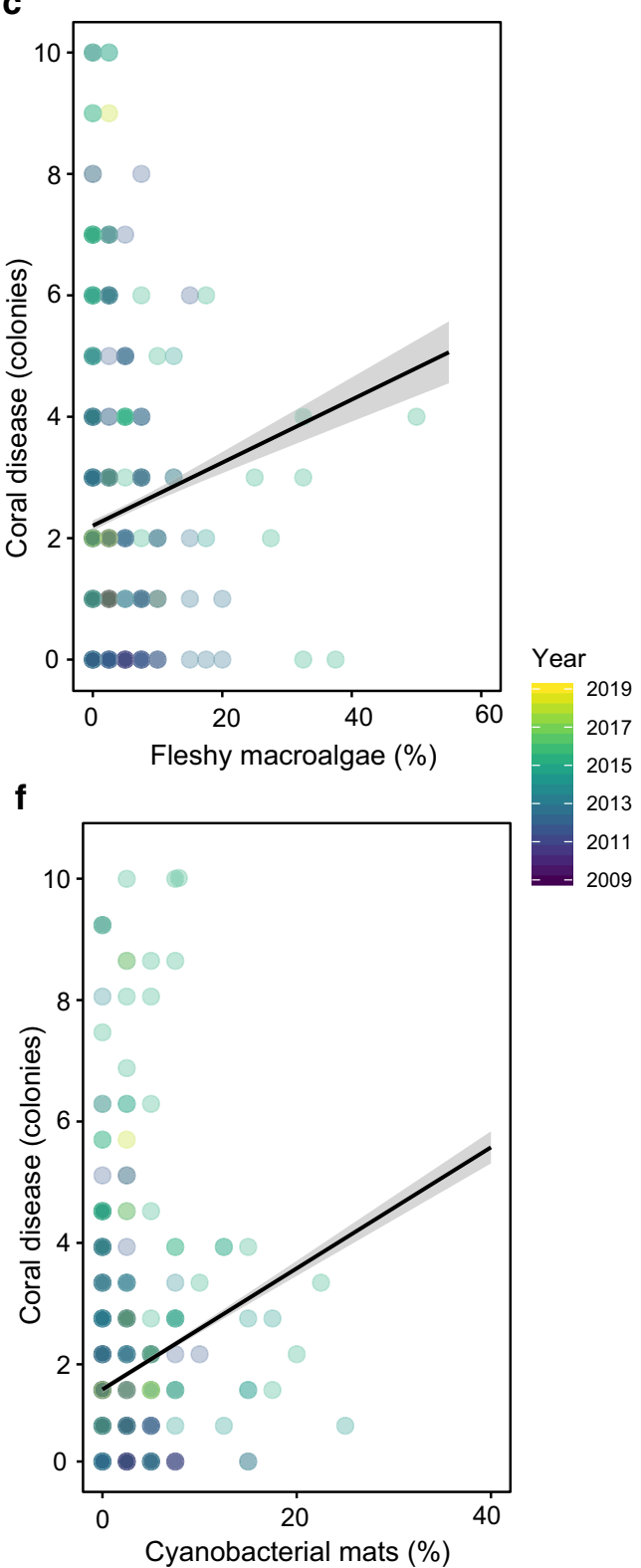

Fig. 7 Predicted changes in hard coral cover $\%(\mathbf{a}, \mathbf{d})$, soft coral cover $\%(\mathbf{b}, \mathbf{e})$ and number of diseased hard coral colonies (c, f) in response to macroalgaland cyanobacterial mats cover $(\%)$. Dots represent the raw data and the lines the model predictions with SE

d, e, ESM Table 46). Increases in fleshy macroalgae and cyanobacterial mats were also significantly related to an increase in the number of diseased hard coral colonies (Fig. 7c, f, Table 46).

Urchin densities were also negatively related to both macroalgae and fleshy algae, whereas damselfishes were only significantly negatively related to cyanobacterial mats (Fig. 8a-c, ESM Table 46). No significant relationship was found between macroalgal or cyanobacterial cover and parrotfish and surgeonfish densities (ESM Table 46).

\section{Discussion}

Changes in coral reef benthic assemblages have been observed worldwide after acute perturbations (e.g. storm, disease outbreak or bleaching event) or chronic disturbances (e.g. nutrient enrichment or overfishing) (e.g. Guest et al. 2016; de Bakker et al. 2017; Adjeroud et al. 2018). Such changes are the result of different species sensibilities to stress and recovery capacities, as well as changes in competition and predation patterns (Darling et al. 2012). In this study, we found that benthic assemblages in coral reefs around Dahab in the Gulf of Aqaba changed considerably 
a

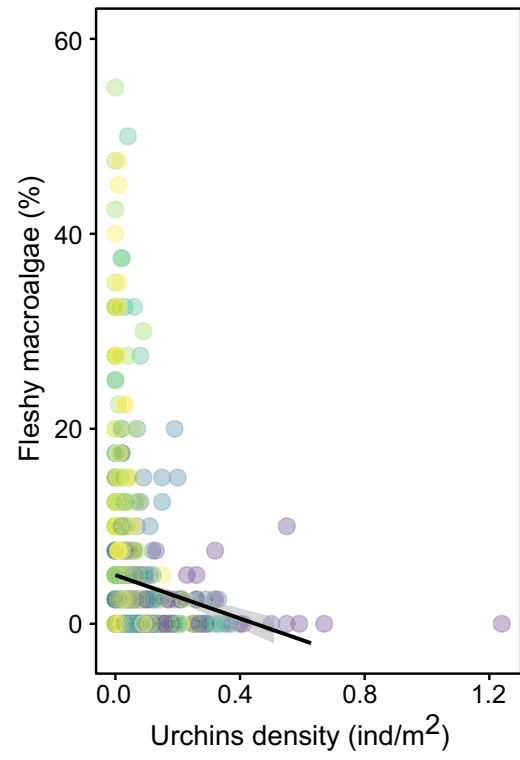

b

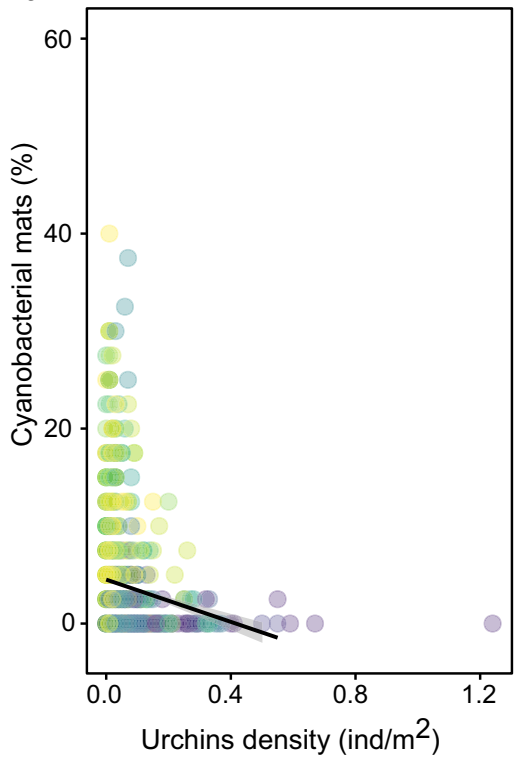

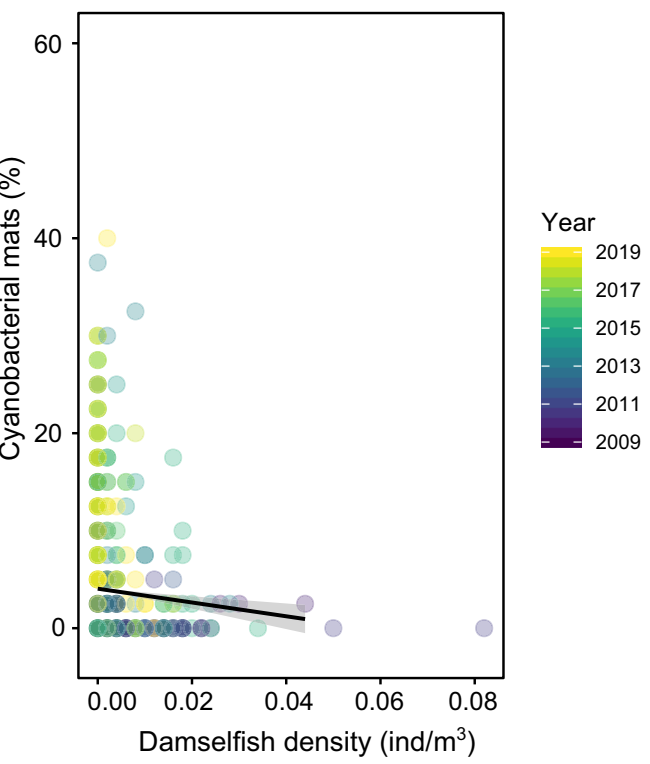

Fig. 8 Predicted changes in macroalgae (a) and cyanobacteria $(\mathbf{b}, \mathbf{c})$ cover $(\%)$ in response to urchins densities (number of individuals $/ \mathrm{m}^{2}$, e) and damselfish densities $\left(\mathrm{n}^{\circ}\right.$ individuals $\left./ \mathrm{m}^{3}, \mathbf{f}\right)$. Dots represent the raw data and the lines the model predictions with SE

between 2009 and 2019. Hard coral cover did not decrease in any of the site groups and was found to significantly increase, mainly due to increases in branching coral (Acropora spp.) in one of the site groups, but no changes in the cover of massive coral cover were found. These results are in contrast with studies from other regions which show a replacement of fast-growing scleractinian coral species with high structural complexity such as branching morphologies (e.g. Acropora spp.) by slower-growing stressresistant corals with foliose or massive morphologies (Darling et al. 2012; McClanahan 2014; Guest et al. 2016; Adjeroud et al. 2018). Tropical storms, predation by crown of thorns and bleaching have been regarded as major factors in the degradation of coral reefs in the Great Barrier Reef (De'ath et al. 2012). The northern Red Sea is not affected by cyclonic storms and its corals display high heat tolerance (Fine et al. 2013; Bellworthy and Maoz 2017), thus it could be possible that species such as Acropora spp. that are normally highly sensitive to thermal stress, but fast-growing and very competitive (Linares et al. 2011, Darling et al. 2012), thrive in this region.

Despite the heterogeneity in Dahab reefs (i.e. shallow fore reefs and reefs slopes), the major changes in the benthic composition in all site groups were characterised by increases in fleshy macroalgae and cyanobacterial mats. In two of the site clusters, we also observed a significant reduction in soft corals. Macroalgae can harm corals and other organisms through allelopathy (Rasher and Hay 2010), shading (Box and Mumby 2007) and physical abrasion (McCook et al. 2001). Cyanobacterial mats are also known to be harmful to reef organisms by producing highly toxic metabolites that can damage tissue or inhibit recruitment (Ritson-Williams et al. 2016) and by producing dissolved organic carbon (DOC) and anoxic environments (Brocke et al. 2015), which can result in coral diseases (Carlton and Richardson 1995). Recent studies show that algal proliferations (including macroalgae and benthic cyanobacteria) can disrupt the coral microbiome and increase pathogenic bacteria, leading to increased coral mortalities (Haas et al. 2016; Zaneveld et al. 2016). Despite the fact that we did not observe significant decreases in hard coral cover during the studied period, we found significant negative relationships between coral (both hard and soft) and macroalgal and cyanobacterial cover. We also found that higher macroalgal and cyanobacterial covers were significantly related with an increase in the number of diseased coral colonies (especially in Skeletal Eroding Band Disease, N. M. personal observation). These results suggest that although hard coral cover in reefs around Dahab was stable throughout the period studied, increasing macroalgal and cyanobacterial cover negatively affects coral reef building species. Therefore, if sustained increases in macroalgal and cyanobacterial biomass occur, Dahab coral reefs could probably undergo degradation. Algal proliferations (macroalgae and cyanobacteria) and declines in coral cover lead to a decrease in the structural complexity of coral reefs, which is in turn associated with lower ecosystem biodiversity and resilience (Graham and Nash 2012; Bozec et al. 2015; Ferrari et al. 2016). Chemical cues from macroalgae and cyanobacteria can also suppress coral and fish larvae recruitment, reinforcing algal dominance and decreasing coral reef recovery 
(Kuffner et al. 2006; Dixson et al. 2014; Ritson-Williams et al. 2016). Recent studies suggest that different coral reefs display different susceptibilities to macroalgae, with moderate macroalgal abundances $(\sim 10 \%)$ disrupting coral recruitment in high resilient French Polynesian coral reefs (Mumby et al. 2016). Therefore, deeper evaluation of algal effects in the functioning of Dahab coral reefs, including in coral recruitment, is needed.

Algal proliferation in coral reefs is thought to be the result of multiple intertwined factors such as the increase in nutrient content and loss of top-down control due to overfishing or disease (Rasher et al. 2012; Jessen et al. 2013). Studies indicate herbivory suppression as the dominant factor for macroalgal increases (Rasher et al. 2012), whereas nutrient increase together with elevated water temperatures would favour cyanobacterial mats proliferation over macroalgae (Kuffner and Paul 2001; de Bakker et al. 2016; Beltram et al. 2019). Although we did not measure the levels of nutrients in this study, a previous short-term study in Dahab reported increases in phosphate and ammonium that were positively related to turf algal increases, suggesting that eutrophication could be an important driver of algal increases in Dahab (Naumann et al. 2015).

The Dahab reefs investigated in this study are located within the Abu Gallum and Nabq Managed Resource Protected Areas, for which fishing permits are solely granted to the local Bedouin tribes for subsistence (Pearson 1998; Galal et al. 2002). Extensive tourism along Egypt's Sinai coast has led to high demand in seafood for establishments catering to visitors, which is partially met through commercial, non-subsistent harvesting (C. v. M. personal observation). Therefore, fishing may play a role in the decrease of herbivorous fish at some study sites and consequent increase in algae. In fact, the largest increases in algae were observed in the site cluster that presented the highest fishing pressures (Rick's Reef, Um Sid). Individual trajectories of fish differed between the different site clusters, but herbivore groups such as parrotfish and surgeonfish decreased in site cluster 3, which displayed the second most important increase in fleshy macroalgae. Damselfishes decreased in all site groups and were negatively related to cyanobacterial cover. Previous studies have shown that larger herbivorous species such as acanthurids are the main contributors to macroalgal control (Ceccarelli et al. 2006; Rasher et al. 2013). Although cyanobacterial top-down control is less understood, partly due to the fact cyanobacteria have been considered largely unpalatable to many broad consumers, recent studies suggest an important role of top-down control on cyanobacterial mats (Capper et al. 2016; Cissell et al. 2019). Previous studies have reported cyanobacteria as an important ingredient in several damselfish species diets
(Lassuy 1984; Feitosa et al. 2012). Therefore, we cautiously propose that a decrease in herbivore damselfishes like those studied here (P. lacrymatus, P. leucozonus and $S$. nigricans) might be at least partly related to the observed cyanobacterial increases. We, however, emphasise the need of more research to explore this hypothesis in order to identify the cyanobacterial species proliferating in Dahab reefs and whether they are consumed or not by herbivore damselfishes.

Urchin densities significantly declined in all Dahab coral reefs between 2009 and 2019, which was mainly attributed to the decline in the long-spined urchins Echinotrix spp. and Diadema spp., and their densities were significantly negatively related to macroalgal and cyanobacterial cover. Grazer urchins such as Diadema are highly effective in controlling algal proliferation (including cyanobacteria) and ensuring space for corals to settle (Sandin and McNamara 2012; Capper et al. 2016). In fact, Diadema antillarum die-off was one of the main drivers initiating algal phase shifts throughout the Caribbean in the 1980s (Carpenter 1990), and its recent recovery in some locations promoted coral recolonisation and growth (Myhre and Acevedo-Gutiérrez 2007; Idjadi et al. 2010). Reasons behind the decreases in long-spined urchins in Dahab reefs, which were especially pronounced in some of the sites (e.g. Canyon North and Canyon South), are unknown. However, further studies should address the reasons behind their decrease and eventually promote conservation strategies, since urchin decline seems to be one of the main drivers behind algal increases in Dahab reefs.

Finally, we also studied the trajectories of other key invertebrate species such as corallivore snails and Tridacna spp. Corallivore snails of the genus Drupella and Coralliophila can be an important source of coral tissue loss and reduced growth if present in high abundances (Hamman 2018). A previous link between coral diseases and Drupella snail abundances was suggested in the Red Sea (Antonius and Riegl 1998) and more recent studies found Drupella spp. are effective vectors of the ciliate responsible for brown band disease $(\mathrm{BrB})$ in the Great Barrier Reef (Nicolet et al. 2013). Other studies suggest that interactive effects between corallivory and other stressors such as overfishing or nutrient pollution can further affect coral resilience (Rice et al. 2019). In our study, we did not find significant increases in the densities of corallivorous snails between 2009 and 2019. Tridacna spp. display varied ecological functions in coral reefs such as increasing topographic heterogeneity and reef accretion, acting as reservoirs of zooxanthellae (Symbiodiniaceae) and limiting eutrophication effects via water filtration (Neo et al. 2015). An experimental study also showed that the presence of clams had significantly positive effects on the richness and abundance of fish species and invertebrates, possibly 
through acting as an important food source (Cabaitan et al. 2008). Giant clam densities in Dahab increased significantly during the surveyed period, although this increase was mainly due to small size $(<20 \mathrm{~cm})$ individuals, whilst the biggest sizes remained stable or declined (N. M., personal observation). During the period studied, we did not record any outbreak of crown of thorns starfish (COTS). However, COTS outbreaks have been previously (between 1998 and 2002) observed in the Egyptian Red Sea coast including Dahab (Ammar et al. 2006; Tilot et al. 2008) and therefore factors related to COTS outbreaks such as fishing pressure and increases in nutrients should be controlled (Babcock et al. 2016).

In summary, coral reef assemblages around Dahab in the Gulf of Aqaba changed considerably between 2009 and 2019. All sites experienced an increase in fleshy macroalgae and cyanobacterial mats, with algae being the most abundant biotic group in 2019 at two site groups. Steep urchin declines, especially in long-spined urchins, were most likely the main driver of the algal increases, although reasons behind such declines remain unknown. Damselfish decline was also related to the increase of cyanobacterial mats, suggesting a possible involvement of top-down control on cyanobacterial mats, but further research is required to confirm this hypothesis. A previous short-term study in Dahab reported high nutrient levels in some reefs (Naumann et al. 2015); therefore, the role of eutrophication in the proliferation of cyanobacterial mats should also be considered and further explored. Despite all site groups displaying similar changes (e.g. macroalgal and cyanobacterial increases and urchin declines), the site group that presented the most moderate macroalgal proliferation was the only cluster to present an increase in hard coral cover, suggesting high resistance in some of the Dahab reefs. However, as the strong relationship between macroalgae/cyanobacteria and coral disease suggests, Dahab coral reef resistance could be compromised if macroalgal increases are not controlled and mitigated.

Acknowledgements Open Access funding provided by Projekt DEAL. Surveys used in this research were conducted under the Dahab Reef Monitoring Programme and approved by RSEC and the Nature Conservation Sector from the Egyptian Environmental Affairs Agency (Proposal 14.12.2006) and in cooperation with the latter and Reef Check Germany. We would like to thank the numerous volunteers who took part in the surveys between 2009 and 2019 and Sinai Divers Backpackers. N. D. received an IYOR2018 scholarship funded by the MareMundi/RSEC, Reef Check Germany and Sinai Divers Backpackers. We would also like to thank George Heiss, the Reef Check coordinator for Europe, for reading and commenting on the manuscript.

\section{Compliance with ethical standards}

Conflict of interest On behalf of all authors, the corresponding author states that there is no conflict of interest.
Open Access This article is licensed under a Creative Commons Attribution 4.0 International License, which permits use, sharing, adaptation, distribution and reproduction in any medium or format, as long as you give appropriate credit to the original author(s) and the source, provide a link to the Creative Commons licence, and indicate if changes were made. The images or other third party material in this article are included in the article's Creative Commons licence, unless indicated otherwise in a credit line to the material. If material is not included in the article's Creative Commons licence and your intended use is not permitted by statutory regulation or exceeds the permitted use, you will need to obtain permission directly from the copyright holder. To view a copy of this licence, visit http://creativecommons. org/licenses/by/4.0/.

\section{References}

Abdelmongy AS, El-Moselhy KM (2015) Seasonal variations of the physical and chemical properties of seawater at the Northern Red Sea, Egypt. Open Journal of Ocean and Coastal Sciences 2:1-17

Adjeroud M, Kayal M, Iborra-Cantonnet C, Vercelloni J, Bosserelle P, Liao V, Chancerelle Y, Claudet J, Penin L (2018) Recovery of coral assemblages despite acute and recurrent disturbances on a South Central Pacific reef. Sci Rep 8:1-8

Ammar MSA, Bouwmeester J, Riegl B, Hausser J, Keck A (2006) Possible causes, consequences of changes and future of coral reefs in Dahab, Gulf of Aqaba, Red Sea, Egypt. Egypt J Aquat Res 32:160-179

Antonius A, Riegl B (1998) Coral diseases and Drupellacornus invasion in the Red Sea. Coral Reefs 17:48-48

Arnold TW (2010) Uninformative parameters and model selection using Akaike's information Criterion. J Wildl Manage 74:1175-1178

Babcock RC, Dambacher JM, Morello EB, Plagányi ÉE, Hayes KR, Sweatman HPA, Pratchett MS (2016) Assessing different causes of crown-of-thorns starfish outbreaks and appropriate responses for management on the Great Barrier Reef. PLOS ONE 11:e0169048

Bahartan K, Zibdah M, Ahmed Y, Israel A, Brickner I, Abelson A (2010) Macroalgae in the coral reefs of Eilat (Gulf of Aqaba, Red Sea) as a possible indicator of reef degradation. Mar Pollut Bull 60:759-764

Barton K (2019) Package "MuMIn": multi-model inference. R package version 1.43 .4

Bates D, Maechler M, Bolker B, Walker S, Christensen RHB, Singmann H, Dai B, Scheipl F, GrothendieckG, Green P, Fox J (2019) Package "Ime4": Linear mixed effect models using "eigen" and S4. R package version 1.1-21

Bell JJ, Davy SK, Jones T, Taylor MW, Webster NS (2013) Could some coral reefs become sponge reefs as our climate changes? Glob Chang Biol 19:2613-2624

Bellwood DR, Hughes TP, Folke C, Nyström M (2004) Confronting the coral reef crisis. Nature 429:827-833

Bellworthy J, Maoz F (2017) Beyond peak summer temperatures, branching corals in the Gulf of Aqaba are resilient to thermal stress but sensitive to high light. Coral Reefs 36:1071-1082

Beltram FL, Lamb RW, Smith F, Witman JD (2019) Rapid proliferation impacts of cyanobacterial mats on Galapagos rocky reefs during 2014-2017 El Niño Southern Oscillation. J Exp Mar BiolEcol 514-515:18-26

Borcard D, Legendre P, Drapeau P (1992) Partialling out the spatial component of ecological variation. Ecology 73:1045-1055 
Box SJ, Mumby PJ (2007) Effect of macroalgal competition on growth and survival of juvenile Caribbean corals. Mar Ecol Progr Ser 342:139-149

Bozec Y-M, Alvarez-Filip L, Mumby PJ (2015) The dynamics of architectural complexity on coral reefs under climate change. Glob Chang Biol 21:223-235

Brocke HJ, Wenzhoefer F, De Beer D, Mueller B, Van Duyl FC, Nugues MM (2015) High dissolved organic carbon release by benthic cyanobacterial mats in a Caribbean reef ecosystem. Sci Rep 5:8852

Bruno JF, Selig ER (2007) Regional decline of coral cover in the Indo-Pacific: timing, extent, and subregional comparisons. PLOS ONE 2:e711

Burkepile DE, Hay ME (2008) Herbivore species richness and feeding complementarity affect community structure and function on a coral reef. PNAS 105:16201-16206

Cabaitan PC, Gomez ED, Aliño PM (2008) Effects of coral transplantation and giant clam restocking on the structure of fish communities on degraded patch reefs. J Exp Mar Biol Ecol 357:85-98

Capper A, Erickson AA, Ritson-Williams R, Becerro MA, Arthur KA, Paul VJ (2016) Palatability and chemical defences of benthic cyanobacteria to a suite of herbivores. J Exp Mar Biol Ecol 474:100-108

Carlton RG, Richardson LL (1995) Oxygen and sulfide dynamics in a horizontally migrating cyanobacterial mat: black band disease of corals. FEMS Microbiol Ecol 18:155-162

Carpenter RC (1990) Mass mortality of Diadema antillarum. Mar Biol 104:67-77

Ceccarelli DM, Hughes TP, McCook LJ (2006) Impacts of simulated overfishing on the territoriality of coral reef damselfish. Mar Ecol Progr Ser 309:255-262

Chaidez V, Dreano D, Agusti S, Duarte CM, Hoteit I (2017) Decadal trends in Red Sea maximum surface temperature. Sci Rep 7:8144

Cissell EC, Manning JC, McCoy SJ (2019) Consumption of benthic cyanobacterial mats of a Caribbean coral reef. Sci Rep 9:12693

Darling E, Alvarez-Filip L, Oliver TA, McClanahan TR, Coté IM (2012) Evaluating life-history strategies of reef corals from species traits. Ecol Lett 15:1378-1386

de Bakker DM, van Duyl FC, Bak RPM, Nugues MM, Nieuwland G, Meesters EH (2017) 40 Years of benthic community change on the Caribbean reefs of Curaçao and Bonaire: the rise of slimy cyanobacterial mats. Coral Reefs 36:355-367

De'ath G, Fabricius KE, Sweatman H, Puotinen M (2012) The 27-year decline of coral cover on the Great Barrier Reef and its causes. PNAS 109:17995-17999

Dixson DL, Abrego D, Hay ME (2014) Chemically mediated behaviour of recruiting corals and fishes: A tipping point that may limit reef recovery. Science 345:892-897

Done TJ (1992) Phase shifts in coral reef communities and their ecological significance. Hydrobiologia 247:121-132

Feitosa JLL, Concentino AM, Teixeira SF, Ferreira BP (2012) Food resource use by two territorial damselfish (Pomacentridae: Stegastes) on South-Western Atlantic algal-dominated reefs. J Sea Res 70:42-49

Ferrari R, Bryson M, Bridge T, Hustache J, Williams SB, Byrne M, Figueira W (2016) Quantifying the response of structural complexity and community composition to environmental change in marine communities. Glob Chang Biol 22:1965-1975

Fine M, Gildor H, Genin A (2013) A coral reef refuge in the Red Sea. Glob Chang Biol 19:3640-3647

Galal N, Ormond RFG, Hassan O (2002) Effects of a network of notake reserves in increasing catch per unit effort and stocks of exploited fish at Nabq, South Sinai, Egypt. Mar Freshwater Res 53(199):205
Gardner TA, Côté IM, Gill JA, Grant A, Watkinson AR (2003) Longterm region-wide declines in Caribbean corals. Science 301:958-960

Graham NAJ, Nash KL (2012) The importance of structural complexity in coral reef ecosystems. Coral Reefs 32:315-326

Guest JR, Tun K, Low J, Vergés A, Marzinelli EM, Campbell AH, Bauman AG, Feary DA, Chou LM, Steinberg PD (2016) 27 years of benthic and coral community dynamics on turbid, highly urbanised reefs off Singapore. Sci Rep 6:36260

Guisan A, Edwards TC, Hastie T (2002) Generalized linear and generalized additive models in studies of species distributions: setting the scene. Ecol Modell 157:89-100

Haas AF, Fairoz MFM, Kelly LW, Nelson CE, Dinsdale EA, Edwards RA, Giles S, Hatay M, Hisakawa N, Knowles B, Lim YW, Maughan H, Pantos O, Roach TNF, Sanchez SE, Silveira CB, Sandin S, Smith JE, Rohwer F (2016) Global microbialization of coral reefs. Nat Microbiol 1:16042

Hamman EA (2018) Aggregation patterns of two corallivorous snails and consequences for coral dynamics. Coral Reefs 37:851-860

Hasler H, Ott JA (2008) Diving down the reefs? Intensive diving tourism threatens the reefs of the northern Red Sea. Mar Pollut Bull 56:1788-1794

Heron SF, Maynard JA, van Hooidonk R, Eakin CM (2016) Warming trends and bleaching stress of the world's coral reefs 1985-2012. Sci Rep 6:38402

Hill J, Wilkinson C (2004) Methods for ecological monitoring of coral reefs. Australian Institute of Marine Science, Townsville

Hoey AS, Bellwood DR (2011) Suppression of herbivory by macroalgal density: a critical feedback on coral reefs? Ecol Lett $14: 267-273$

Hughes TP, Anderson KD, Connolly SR, Heron SF, Kerry JT, Lough JM, Baird AH, Baum JK, Berumen ML, Bridge TC, Claar DC, Eakin CM, Gilmour JP, Graham NAJ, Harrison H, Hobbs J-PA, Hoey AS, Hoogenboom M, Lowe RJ, McCulloch MT, Pandolfi JM, Pratchett M, Schoepf V, Torda G, Wilson SK (2018a) Spatial and temporal patterns of mass bleaching of corals in the Anthropocene. Science 359:80-83

Hughes TP, Barnes ML, Bellwood DR, Cinner JE, Cumming GS, Jackson JBC, Kleypas J, van de Leemput IA, Lough JM, Morrison TH, Palumbi SR, van Nes EH, Scheffer M (2017) Coral reefs in the Anthropocene. Nature 546:82-90

Hughes TP, Kerry JT, Baird AH, Connolly SR, Dietzel A, Eakin CM, Heron SF, Hoey AS, Hoogenboom MO, Liu G, McWilliam MJ, Pears RJ, Pratchett MS, Skirving WJ, Stella JS, Torda G (2018b) Global warming transforms coral reef assemblages. Nature 556:492-496

Idjadi JA, Haring RN, Precht WF (2010) Recovery of the sea urchin Diadema antillarum promotes scleractinian coral growth and survivorship on shallow Jamaican reefs. Mar Ecol Progr Ser 403:91-100

Jessen C, Roder C, Lizcano JFV, Voolstra CR, Wild C (2013) In-Situ effects of simulated overfishing and eutrophication on benthic coral reef algae growth, succession, and composition in the Central Red Sea. PLOS ONE 8:e66992

Kuffner IB, Paul VJ (2001) Effects of nitrate, phosphate and iron onthe growth of macroalgae and benthic cyanobacteria from Cocos Lagoon, Guam. Mar Ecol Prog Ser 222:63-72

Kuffner IB, Walters LJ, Becerro MA, Paul VJ, Ritson-Williams R, Beach KS (2006) Inhibition of coral recruitment by macroalgae and cyanobacteria. Mar Ecol Prog Ser 323:107-117

Lamb JB, Willis BL, Fiorenza EA, Couch CS, Howard R, Rader DN, True JD, Kelly LA, Ahmad A, Jompa J, Harvell CD (2018) Plastic waste associated with disease on coral reefs. Science 359:460-462 
Lassuy DR (1984) Diet, intestinal morphology and nitrogen assimilation efficiency of damselfish Stegastes lividus in Guam. Env Biol Fish 10:183-193

Linares C, Pratchett MS, Coker DK (2011) Recolonisation of Acropora hyacinthus following climate-induced coral bleaching on the Great Barrier Reef. Mar Ecol Progr Ser 438:97-104

McClanahan TR (2014) Decadal coral community reassembly on an African fringing reef. Coral Reefs 33:939-950

McCook L, Jompa J, Diaz-Pulido G (2001) Competition between corals and algae on coral reefs: a review of evidence and mechanisms. Coral Reefs 19:400-417

McWilliam M, Pratchett MS, Hoogenboom MO, Hughes TP (2020) Deficits in functional trait diversity following recovery on coral reefs. Proc Roy Soc B: Biol Sci 287:20192628

Mumby PJ, Steneck RS, Adjeroud M, Arnold SN (2016) High resilience masks underlying sensitivity to algal phase shifts of Pacific coral reefs. Oikos 125:644-655

Myhre S, Acevedo-Gutiérrez A (2007) Recovery of sea urchin Diadema antillarum populations is correlated to increased coral and reduced macroalgal cover. Mar Ecol Progr Ser 329:205-210

Naumann MS, Bednarz VN, Ferse SCA, Niggl W, Wild C (2015) Monitoring of coastal coral reefs near Dahab (Gulf of Aqaba, Red Sea) indicates local eutrophication as potential cause for change in benthic communities. Environ Monit Assess 187:44

Neo ML, Eckman W, Vicentuan K, Teo SL-M, Todd PA (2015) The ecological significance of giant clams in coral reef ecosystems. Biol Conserv 181:111-123

Nicolet KJ, Hoogenboom MO, Gardiner NM, Pratchett MS, Willis BL (2013) The corallivorous invertebrate Drupella aids in transmission of brown band disease on the Great Barrier Reef. Coral Reefs 32:585-595

Norström AV, Nyström M, Lokrantz J, Folke C (2009) Alternative states on coral reefs: beyond coral-macroalgal phase shifts. Mar Ecol Progr Ser 376:295-306

Oksanen J, Blanchet FG, Kindt R, Legendre P, Minchin PR, O'hara RB, Simpson GL, Solymos P, Stevens MHH, Wagner H (2019) Package "vegan": community ecology package. R package version 2.5-6

Osman EO, Smith DJ, Ziegler M, Kürten B, Conrad C, El-Haddad KM, Voolstra CR, Suggett DJ (2018) Thermal refugia against coral bleaching throughout the northern Red Sea. Glob Chang Biol 24:e474-e484

Pandolfi JM, Bradbury RH, Sala E, Hughes TP, Bjorndal KA, Cooke RG, McArdle D, McClenachan L, Newman MJH, Paredes G, Warner RR, Jackson JBC (2003) Global trajectories of the longterm decline of coral reef ecosystems. Science 301:955-958

Pearson MP (1998) Protectorates Management in the Arab Republic of Egypt: the South Sinai Management Sector Serving the Needs of Conservation and Development. Egyptian Environmental Affairs Agency, Cairo
Peres-Neto PR, Legendre P, Dray S, Borcard D (2006) Variation partitioning of species data matrices: estimation and comparison of fractions. Ecology 87:2614-2625

Rasher DB, Engel S, Bonito V, Fraser GJ, Montoya JP, Hay ME (2012) Effects of herbivory, nutrients, and reef protection on algal proliferation and coral growth on a tropical reef. Oecologia 169:187-198

Rasher DB, Hay ME (2010) Chemically rich seaweeds poison corals when not controlled by herbivores. PNAS 107:9683-9688

Rasher DB, Hoey AS, Hay ME (2013) Consumer diversity interacts with prey defenses to drive ecosystem function. Ecology 94:1347-1358

Rasul NMA, Stewart ICF, Nawab ZA (2015) Introduction to the Red Sea: Its Origin, Structure, and Environment. In: Rasul NMA, Stewart ICF (eds) The Red Sea. The Formation, Morphology, Oceanography and Environment of a Young Ocean Basin. Springer, Berlin, pp 1-28

Rice MM, Ezzat L, Burkepile DE (2019) Corallivory in the anthropocene: interactive effects of anthropogenic stressors and corallivory on coral reefs. Front Mar Sci 5:525

Rinkevich B (2005) What do we know about Eilat (Red Sea) reef degradation? A critical examination of the published literature. J Exp Mar Biol Ecol 327:183-200

Ritson-Williams R, Ross C, Paul VJ (2016) Elevated temperature and allelopathy impact coral recruitment. PlosOne 11:e016658

Sandin SA, McNamara DE (2012) Spatial dynamics of benthic competition on coral reefs. Oecologia 168:1079-1090

Tilot V, Leujak W, Ormond RFG, Ashworth JA, Mabrouk A (2008) Monitoring of South Sinai coral reefs: influence of natural and anthropogenic factors. Aquat Cons 18:1109-1126

van Hooidonk R, Maynard JA, Manzello D, Planes S (2014) Opposite latitudinal gradients in projected ocean acidification and bleaching impacts on coral reefs. Glob Chang Biol 20:103-112

Williams I, Polunin N (2001) Large-scale associations between macroalgal cover and grazer biomass on mid-depth reefs in the Caribbean. Coral Reefs 19:358-366

Zakai D, Chadwick-Furman NE (2002) Impacts of intensive recreational diving on reef corals at Eilat, northern Red Sea. Biol Cons 105:179-187

Zaneveld JR, Burkepile DE, Shantz AA, Pritchard CE, McMinds R, Payet JP, Welsh R, Correa AMS, Lemoine NP, Rosales S, Fuchs C, Maynard JA, Thurber RV (2016) Overfishing and nutrient pollution interact with temperature to disrupt coral reefs down to microbial scales. Nat Comm 7:11833

Publisher's Note Springer Nature remains neutral with regard to jurisdictional claims in published maps and institutional affiliations. 